p-ISSN. 2086-9029

e-ISSN. 2654-5675

Vol. 22 No. 2, HIm. 159-352, Desember 2020

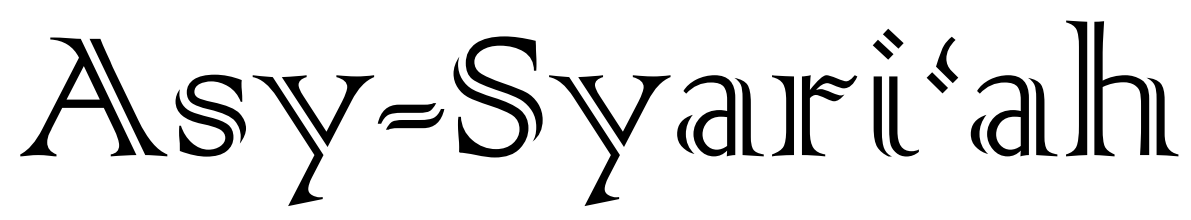

- Implementasi Prinsip Keadilan dalam Hukum Perjanjian Syari'ah

$(159-178)$ Zaenudin Mansyur

- Akad Rahn Tasyjili pada Gadai Tanah Pertanian di Pegadaian Syariah

$(179-196)$ Rahmadi Indra Tektona, Dyah Ochtorina Susanti

- Potensi Sertifikasi Halal dalam Mengahadapi Masyarakat Ekonomi

$(197-218)$ ASEAN

Deviana Yuanitasari, Helitha Noviana Dewi

- Akad Mudharabah sebagai Instrumen Pendanaan dan Pembiayaan di

$(219-236)$ Lembaga Keuangan Syariah

Asep Dadang Hidayat, Moh. Sar'an

- Praktik Rekayasa Dispensing Pump SPBU Persfektif Peraturan

$(237-258)$ Perundang-Undangan dan Hukum Islam

Hazar Kusmayanti, Ratu Chairunissa

- Dinamika Penerapan Akad Syariah dalam Produk Keuangan di Bank

$(259-274)$ Syariah

Jaenudin

- Etika Bisnis Islam pada Perilaku Pemasaran dan Kepuasan Konsumen

$(275-290)$ Wida Ramdania

- Kebijakan Fiskal Islam pada Masa Al-Khilafah Al-Islamiyah

Supriatna, Dedah Jubaedah

- Pelanggaran Prinsip Tanggungjawab Perusahaan Asuransi Investasi Persfektif Perundang-Undangan dan Hukum Ekonomi Syariah

Yoghi Arief Susanto, Yeti Sumiyati

- Identifikasi Kebutuhan Pembiayaan Syariah Peternak Lembu di Deli (337-352) Serdang

Marlya Fatira AK, Anriza Witi Nasution, Tuti Kurnia

FACULTY OF SHARIA AND LAW

STATE ISLAMIC UNIVERSITY SUNAN GUNUNG DJATI BANDUNG-INDONESIA IN COLLABORATION WITH ASOSIASI SARJANA SYARIAH INDONESIA 


\section{Asy-Syari'ah}

Volume 22, Number 2, 2020

\section{EDITOR-IN-CHIEF}

Ine Fauzia

\section{EDITORIAL BOARD}

Sofyan al-Hakim, UIN Sunan Gunung Djati Bandung, Indonesia Deni Kamaludin Yusup, UIN Sunan Gunung Djati Bandung, Indonesia

Meria Utama, Fakultas Hukum Univrsitas Sriwijaya, Indonesia

Dewi Mayaningsih, UIN Sunan Gunung Djati Bandung, Indonesia

Andrey Sujatmiko, Fakultas Hukum Universitas Trisakti, Jakarta, Indonesia

Hetty Hassanah, Universitas Komputer Indonesia, Indonesia

Tarun Ghawana, CDMS, New Delhi, India

Muhammad Hasanuddin, UIN Sunan Gunung Djati Bandung, Indonesia

Syahrul Anwar, UIN Sunan Gunung Djati Bandung, Indonesia

Aden Rosadi, UIN Sunan Gunung Djati Bandung, Indonesia

\section{PEER-REVIEWERS}

S. Salahudin Suyurno, Universiti Teknologi MARA (UiTM) Melaka, Malaysia

Ezani Yaakub, Universiti Teknologi MARA (UiTM) Malaysia, Malaysia

Zezen Zaenal Mutaqin, University of California, Los Angeles, United States

Muhammad Irfan Helmy, IAIN Salatiga, Semarang, Indonesia

Ahmad Ali Nurdin, UIN Sunan Gunung Djati Bandung

Tajul Arifin, UIN Sunan Gunun Djati Bandung, Indonesia

Mohamad Anton Athoillah, UIN Sunan Gunung Djati Bandung, Indonesia

Renny Supriyatni, Universitas Padjadjaran, Indonesia

Ahmad Tholabi Karlie, UIN Syarif Hidayatullah Jakarta, Indonesia

Ija Suntana, UIN Sunan Gunung Djati Bandung, Indonesia

Ahmad Fathonih, UIN Sunan Gunung Djati Bandung, Indonesia

Fauzan Ali Rasyid, UIN Sunan Gunung Djati Bandung, Indonesia

Rahman Syamsuddin, Universitas Islam Negeri Alauddin Makassar, Indonesia

\section{PROOFREADER/DESIGN COVER}

Nanang Sungkawa

\section{LAYOUT EDITOR}

Opik Rozikin

Asy-Syari'ah has been accredited by The Ministry of Education and Cultere, Republic of Indonesia as an academic journal in Sinta 3 (SK Diirjen Penguatan Riset dan Pengembangan Kemristekdikti No. 14/E/KPT/2019), valid for 5 years from Volume 19 No. 1 Tahun 2017 until Volume 23 No. 2 Tahun 2022. 


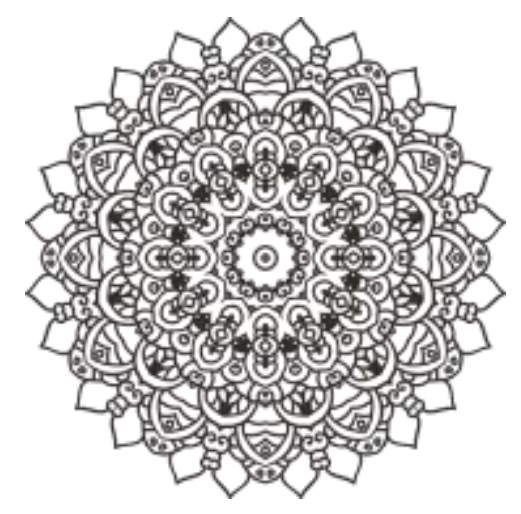

\title{
IMPLEMENTASI PRINSIP KEADILAN DALAM HUKUM PERJANJIAN SYARI'AH
}

\author{
Zaenudin Mansyur \\ Fakultas Syariah Universitas Islam Negeri Mataram \\ E-mail: zain_nahwa@yahoo.com
}

\begin{abstract}
This paper will examine the implementation of the eighth values which appear to be unclear in transactions and sharia agreements, especially in the aspects of the preprocess agreement, process, and post-process. Meanwhile, the use of descriptive analysis method with the provision of the theory of justice can reveal the extent to which the value of justice can be implemented for the parties in the study. Thus, procedural justice is implemented in determining the subject of the agreement at least tamyiz in the pre-process, namely the parties are able to take responsibility for their own agreements which are not the responsibility of others even though the parents themselves. While in the stage of the justice process it is also often part of what can be implemented in an agreement. For example implementing proportional justice in qabul consent. Because the purpose of the stipulation is to know the extent of the readiness and willingness of each party in the agreement. Whereas in the post-process process, the value of justice can also be implemented in the form of the transfer or implementation of rights and obligations for each party. Where the value of justice in this condition is al-mizan or the similarity of scales in terms of quality and quantity.
\end{abstract}

Keywords: Implementation; Fairness; Shariah Agreement 
Abstrak: Tulisan ini bertujuan untuk mengkaji implementasi prinsip kedilan dalam transaksi perjanjian syaria 'ah pada aspek pra proses perjanjian, proses, dan pasca proses. Penelitian ini menggunakan metode analisis deskriptif untuk mengetahui bagaimana prinsip keadilan itu dapat diimplementasikan oleh para pihak pada hukum perjanjian syariah. Hasil penelitian menunjukkan bahwa prinsip keadilan dalam perjanjian syariah dapat ditunjukan dengan terpenuhinya rukun akad yang terdiri dari subjek hukum dan objek pernajian, ijab qabul, kausa halal. Subjek hukum dalam Pra proses harus memenuhi syarat minimal tamyiz artinya mampu mempertanggungjawabkan sendiri perjanjian yang dilakukannya bukan tanggungjawab orang lain meskipun orang tua sendiri. Pada tahap proses perjanjian harus terjadi keseimbangan hak dan kewajiban antara kedua belah pihak dalam ijab qabul. Dalam pasca proses, prinsip keadilan diimplementasikan dalam bentuk penyerahan atau pelaksanaan hak dan kewajiban bagi masing-masing pihak. Melalui ketiga tahapan proses tersebut kedua belah pihak akan sama-sama terikat dalam perjanjian yang sesuai dengan prinsip keadilan.

Kata-Kata Kunci: Implementasi; Prinsip Keadilan; Perjanjian Syari’ah 


\section{Pendahuluan}

Keadilan merupakan bagian inhern yang tidak bisa dipisahkan dari berbagai bidang kehidupan manusia di dunia. Buktinya dapat dicermati dari fitrahnya yang terus menuntut keadilan baik di dunia maupun di akhirat. Di dunia manusia berlomba berusaha dengan berbagai kemampuannya demi memperoleh suatu keadilan. Keadilan dalam bidang politik adalah bagian yang tak kalah pentingnya untuk diperjuangkan agar mendapatkan hak dan kewajiban yang sama di lokalitas negara. Keadilan muncul didasari atas kekecewaan rakyat terhadap pemimipin yang menjalani roda kepemimpinan yang tidak sesuai dengan kehendak rakyatnya yang telah terakomodir dalam undang-undang negara. Pentingnya keadilan dalam bidang politik setidaknya dapat memproduk sikap politikus untuk menjadikannya sebagai slogan serta medium untuk memperoleh kepentingan kekuasaan tertentu, ${ }^{1}$ meskipun dasar-dasar pokoknya adalah al-Qur'an dan al-Sunnah. ${ }^{2}$

Selain itu, terdapat juga keadilan spiritual teologis yang didasarkan pada kondisi manusia yang tidak bisa lepas dari kepercayaannya bahwa ia sebagai pernyataan akal budi, pernyataan kehendak Ilahi, pernyataan usaha manusia, ungkapan kecintaan dan keindahan, dan lain-lain. ${ }^{3}$ Sedangkan tuntutan untuk mendapatkan keadilan ekonomi dimotivasi oleh sistem perekonomian kapital ${ }^{4}$ yang condong eksploitatif dan dalam mendistribusikan kekayaan hanya beredar di kalangan masyarakat status quo (tokoh ekonomi) yang sama sekali tidak mempedulikan kaum mustadh 'afin ${ }^{5}$ sehingga antitesisnya dapat menimbulkan kesan tidak baik semisal borjuis, rakus, ekspolitatif, monofolis, dan lain sebagainya. Sementara itu, kebutuhan manusia untuk mendapatkan keadilan hukum banyak ditengarai oleh keputusan-keputusan pihak penjamin keadilan (hakim) yang tidak sesuai dengan fakta realistis, sehingga kesan busuk yang muncul di permukaan masyarakat menjadi fakta yang tidak bisa diabaikan. Begitu juga bentuk dan jenis dari munculnya politik-politik lainnya karena tidak luput dari persoalan yang dianggap memudharatkan masyarakat. Tuntutan manuisa untuk mendapatkan keadilan tidak hanya berlaku pada aspek bidang keadilan di atas melainkan keadilan sosial sangat emergensi untuk diterapkan. Apalagi telah menyentuh ranah transaksi mu'amalat seperti kontrak,

\footnotetext{
${ }^{1}$ A.A.A. Fyzee., Law in the Middle East (Wasington: D.C, 1955), 5.

${ }^{2}$ Imam Syafi i, al-Risalah (Kairo: Mustafa Bab al-Halabi, 1969), 201.

${ }^{3}$ Zakiyuddin Baidhawy, Rekonstruksi Keadilan, Etika Sosial Ekonomi Islam untuk Kesejahteraan Umum (Surabaya: Jb. Books, 2007), 27.

${ }^{4}$ M. Umer Chapra, Islam an The Ekonomic Challenge (Herndon: IIIT, 1992), chap. I.

${ }^{5}$ Hans Wer, A Dictionary of Modern Written Arabic, Arabic-English (Beirut: Librairie du Liban, 1980), hlm, 451; Majma' al-Lughah al-Arabiyah, Mu'jam Alfazh al-Qur'an al-Karim (Kairo: Al-Idarah al-'Ammah li alMu'jamat wa Ihya' al-Turats al-Arabi, 1989), Kata mustadh 'afin berasal dari akar kata dha'ufa. Kata ini memiliki ragam makna, yaitu lemah, kurus, sakit, dan hilang kekuatannya atau kesehatannya. Sedangkan mustadh 'afin yang bentuk jama 'nya mustadh 'afin atau mustadh 'afun berasal dari istadh 'afa berarti dihina, diremehkan atau dianggap sebagai orang-orang lemah. Dengan demikian, merujuk pada makna kata istadh 'afa dan mustadh 'afun dapat disimpulkan bahwa mustadh 'afin adalah orang-orang yang dianggap lemah dan rendah oleh orang-orang yang kuat sehingga orang-orang kuat ini menindas dan berbuat semena-mena terhadap mereka. hlm, 560 .
} 
perikatan, perutangan, dan perjanjian. Semuanya sangat membutuhkan nilai keadilan agar transaksi yang dilakukan tidak hanya bertujuan untuk terselenggaranya praktek pertukaran antara kedua belah pihak semata tetapi terjaminnya nilai kemaslahatan sosial yang dapat diimplementasikan dengan terjalinnya ukhuwah islamiyah yang berkesinambungan.

Perjanjian merupakan salah satu sumber yang dapat memproduk jenis pertukaran lainnya. ${ }^{6}$ Baik buruknya sebuah perikatan, kontrak, dan perhutangan dapat diukur dari baik buruknya praktik perjanjian yang dilakukan oleh para pihak. Dengan demikian, mewaspadai kesan-kesan buruk dalam perjanjian merupakan persoalan emergensi untuk dijaga. Banyak transaksi-transaksi atau perjanjian dalam realitas pertukaran yang menimbulkan sikap saling benci, penyesalan, dan kerugian di antara kedua belah pihak. Penyebabnya tidak lain karena ketidaksempurnaan dalam mempraktikkan perjanjian. Padahal dari perspektif teologis ${ }^{7}$ dan realita praktis dituntut untuk melaksanakannya secara sempurna serta berusaha mewaspadai segala kemungkinan yang terjadi di kemudian hari. Termasuk berusaha mengimplementasikan nilai-nilai keadilan di dalamnya sehingga illat kemaslahatan untuk maqhasid syari'ah-nya dapat terjaga dengan sempurna. Karena itu, tulisan ini mencoba mendiskripsikan teori keadilan dalam praktik perjanjian sehingga dapat tersingkap tabir yang menghalanginya sebagai bagian yang tidak bisa terpisahkan dari aspek perjanjian.

\section{Metodolgi}

Penelitian ini mencoba mengungkap implementasi nilai-nilai keadilan dalam perjanjian syariah yang nampak misterius karena nilai keadilan tersebut apakah eksis dalam perjanjian syariah atau bahkan tidak ada sama sekali. Untuk mengetahuinya artikel ini menggunakan metode diskriptif kualitatif dalam jenis penelitian kepustakaan. ${ }^{8}$ Adapun teknis pengumpulan data melalui data primer yang mengacu pada pengutipan data-data dari buku, dokumen, dan artikel jurnal yang relevan. ${ }^{9}$ Sedangkan data sekunder tetap menjadi pertimbangan dalam rangka memperkuat data primer melalui penelusuran terhadap dokumen-dokuemen yang berkaitan dengan keadilan dalam perjanjian syariah. Sedangkan hasil penelitian dapat diungkap melalaui metode analisis deskriptif analitis melalui teori keadilan yang dibenturkan terhadap objek penelitian yang dikaji. ${ }^{10}$

\footnotetext{
${ }^{6}$ Wahbah az-Zuhaili, Fiqh Islam wa Adilatuhu (Damaskus: Dar al-Fikr, 1989), hlm, 9.

${ }^{7}$ Pe jelasannya dapat dilihat dalam Qs., al-Ma'idah (5) ayat: 1.

${ }^{8}$ Burhan Ahshafa, Metodologi Penelitian Hukum (Jakarta: Reneka Cipta, 1998), hlm, 15.

${ }^{9}$ Lexy J. Moleong, Metodologi Penelitian Kualitatif (Bandung: Remaja Rosda Karya, 1989), hlm, 206208.

${ }^{10}$ Soerjono Soekanto, Pengantar Penelitian Hukum (Jakarta: Universitas Indonesia Press, 1986), hlm, 


\section{Terma Keadilan dalam Perspektif al-Qur'an}

Keadilan adalah suatu medan semantik yang sangat kaya untuk dieksplorasi. Penelusuran secara kebahasaan atas terma ini sangat bermakna sebagai dasar pijak dalam melakukan teorisasi keadilan sebagai suatu konstruk pengetahuan ilmiah yang dapat disistematisasi sekaligus dapat dikaji ulang. Penelusuran ini menyediakan basis bagi interpretasi produktif untuk melahirkan makna (meaning) dan pemahaman yang memperkaya khazanah keilmuan dalam bidang ekonomi Islam. Karena itu tidak ironis kalau kemudian al-Qur'an mendeskripsikan terma keadilan itu dengan berbagai kata yang berbeda secara eksplisit meskipun maknanya tidak jauh berbeda. Kurang lebih ada tujuah kata yang dipergunakan al-Qur'an untuk menjelaskan konsep keadilan itu.

Pertama, al-'adl yang berasal dari kata 'adl (عدل) yang artinya secara etimologi adalah keteguhan jiwa atau istiqamah, lawan dari kata penyimpangan (al-jawar). Sedangkan keadilan sebagai suatu konsep dinyatakan dengan ungkapan al- 'adl dan al'idl. ${ }^{11}$ Keduanya memiliki kedekatan makna tetapi penggunaannya sedikit berbeda. Dimana kata pertama lebih digunakan pada persoalan-persoalan hukum. ${ }^{12}$ Sedangkan yang terakhir berkaitan dengan sesuatu yang dipahami melalui daya perasa atau indera seperti timbangan, kuantitas, dan takaran. ${ }^{13}$ Dalam perspektif al'-Qur'an kata al-'adl dengan berbagai derifasi-nya disebut sebanyak 28 kali. ${ }^{14} \mathrm{Hal}$ ini menggambarkan bahwa teori keadilan sangat penting untuk diimplemntasikan dalam berbagai bidang kehidupan manusia. Termasuk dalam aspek transaksi mu'amalat seperti pertukaran, perutangan, kontrak, perikatan, dan perjanjian. di samping disebut dengan kata al-'adl, keadilan itu juga lazim disebut dengan kata al-'adalah. Kata ini mengindikasikan adanya aspek-aspek yang terkandung di dalamnya seperti yang dijelaskan secara konprehensif dalam alQur'an, ${ }^{15}$ yaitu keadilan dalam bidang hukum, ${ }^{16}$ keadilan dalam perkataan atau ucapan atau jujur tidak dusta dan bohong, ${ }^{17}$ keadilan dalam arti tebusan (al-fidyah), ${ }^{18}$ keadilan yang berkaitan dengan perbuatan mempersekutukan Allah, ${ }^{19}$ keadilan yang berhubungan dengan struktur anatomi tubuh manusia yang diciptakan sempurna secara proporisonal. ${ }^{20}$

Kedua, keadilan bermakna al-Qisth. Kata ini tersebar dalam al-Qur'an sebanyak 25 kali dengan berbagai bentuk dan derifasinya. Terma al-qisth bermakna membagi dengan adil (al-nasib wa al-'adl), ia juga bermakna al-mizan, al-hishshah dan al-nasib. Dalam

\footnotetext{
${ }^{11}$ Lawis Ma 'aluf, Kamus al-Munjid (Beirut: t.t.p, 1997), hlm, 491.

12 J. Million Cowan, A Dictionary of Modern Written Arabic (New York: t.t.p, 1976), hlm, 336-337.

${ }^{13}$ Al-Raghib Al-Isfahani, Mu 'jam Mufradat al-Fazh al-Qur'an (Beirut: Dar al-Fikr, n.d.), hlm, 36-37.

${ }_{14}$ Muhammad Fu'ad Abdul Baqi, al-Mu'jam alMufahras li al-faz al-Qur'an al-Karim (Jakarta: Maktab

${ }^{15}$ Ibnu Manzur, Lisan al-Arab (Beirut: Dar al-Shadr, 1990), jilid 11, hlm, 431.

${ }^{16}$ Dapat dilhat penjelasannya dalam Os., an-Nisa (4) ayat: 58.

${ }^{17}$ Qs., al- 'An 'am (6) ayat: 152.

${ }^{18}$ Os., al-Baqarah (2) ayat: 48.

${ }^{19}$ Os., al-'An'am (6) ayat: 1.

${ }^{20}$ Os., al-Infithar (82) ayat: 7.
} Dahlan, n.d.), hlm, 569-570. 
banyak hal kata al-qisth dimaknai sama dengan taqhasatha yang berarti membagikan sesuatu secara adil dan sama. ${ }^{21}$ Artinya pembagian sesuatu yang bermakna al-Qisth adalah sama rata atau dengan lain kata satu banding satu (1:1). Jadi ukuran keadilan menurut makna al-qisth adalah seimbang meskipun nampaknya berseberangan dengan makna keadilan yang sebenarnya.

Ketiga, makna keadilan menjadi al-mizan dan wasath. Yang pertama ini lebih menunjukkan makna pentingnya menciptakan keseimbangan (tawazun), sementara kedua mengandung pengertian sikap moderat (tawassuth) dalam kehidupan. At-tawazun artinya menimbang sesuatu dengan yang lain yang semisal. Begitu juga al-mizan dalam arti alkitab yang diturunkan Allah penting untuk mengukur atau menakar kegiatan mu'amalah manusia di dunia secara adil. Istilah mizan ini termaktub dalam al-Our'an sebanyak 23 kali. $^{22}$ Kebanyakan dari ayat-ayat tersebut sangat erat kaitannya dengan persoalan ekonomi berupa menimbang dan takaran. Terutama dalam kaitannya dengan lalu lintas perdagangan maupun pertukaran yang dilakukan oleh para pihak.

Keempat, keadilan bermakna al-wasath. Secara etimologi al-wasath sesuatu yang terletak di dua ujung. Kata ini tertulis sebanyak lima kali dalam al-Qur'an yang mencakup tiga pengertian, yaitu pertengahan, ${ }_{1}^{23}$ keadilan, ${ }_{1}{ }^{24}$ terbaik. ${ }^{25}$ Makna al-wasath yang kedua menurut Wahbah al-Zuhaily dalam tafsir al-Munir menjelaskan bahwa al-wasath dalam ayat tersebut dinyatakan umat muslim adalah umat yang adil, ${ }^{26}$ yang pada hakikatnya melukiskan suatu keadaan yang terbaik dan terpuji dalam hal anugerah, ciptaan, syari'at, hukum, ibadah, keistimewaan dan fitrah. ${ }^{27}$ Karena itu umat muslim disebut sebagai alwasath karena mereka mengutamakan prinsip keseimbangan (al-mizan) antara kebutuhan jasmani dan rohani, anatar kemaslahatan dunia dan akhirat. Mereka juga berlomba-lomba untuk menjadi kaum yang moderat dan tawassuth $^{28}$ dalam arti memberikan hak kepada yang berhak menerima, melaksanakan secara seimbang, segala hak dan kewajiban dalam suatu konstruk kehidupan sosial baik untuk kepentingan berjangka pendek maupun berjangka panjang. Karena sifat al-wasath dan al'adl itulah umat muslim dijadikan sebagai ummat wasath. ${ }^{29}$

${ }^{21}$ Os., an-Nisa' (4) ayat: 3 dan 115.

22 Pengertian al-mizan sebagai timbangan yang erat kaitannya dengan persoalan ekonomi perdagangan dapat dilihat dalam Os., al-Isra' (17) ayat: 35. Os., al-A'raf (7) ayat: 8-9. Os., al-Oari'ah (101) ayat: 6-8.

${ }^{23}$ Ibnu Manzur, Lisan...., 426-428. Sebagai bukti pemaknaan adil menjadi wasath seperti tertera dalam Os., al-Baqarah (2) ayat: 238, Os., al-'adiyat (100) ayat: 5.

${ }^{24}$ Os., al-Baqarah (2) ayat: 143.

${ }^{25}$ Os., al-Ma'idah (5) ayat:89.

${ }^{26}$ Wahbah az-Zuhaili, Tafsir al-Munir al- 'Aqidah wa al-Syari'ah wa al-Manhaj (Beirut: Dar al-Fikr, 1991), hlm, 14-15.

${ }^{27}$ Ibnu Katsir, Tafsir al- 'Azhim (Beirut: Dar al-Fikr, 1982), jilid 1, hlm, 190-191.

${ }^{28}$ Mustafa Al-Maraghi, Tafsir al-Maraghi (Beirut: Dar al-Fikr, 1944), 5-6.

${ }^{29}$ Rosihan A. Rasyid, Penyelarasan Diberlakukannya Hukum Acara Perdata Peradilan Umum Sebagai Hukum Acara Peradilan Agama Khusus dari Segi Pembuktian Zina dalam Mimbar Hukum Aktualisasi Hukum Islam (Jakarta: Direktorat Pembinaan Badan Peradilan Agama Islam, 1992), jilid II, hlm, 4-5. 
Kelima, keadilan bermakna al-Oashd (jalan lurus)..$^{30}$ Kata ini dalam berbagai bentuknya disebutkan enam kali dalam al-Our'an karena mengandung beberapa pengertian antara lain: pertama, al-Iqtishad, yaitu suatu sikap antara kelebihan dan bakhil, antara cepat dan lambat, antara jauh dan dekat. ${ }^{31}$ Begitu juga bisa berarti hemat yang menegaskan sikap manusia antara berlebihan dan kekurangan. Kedua, dalam arti tercela yang menegaskan bahwa iqtishad itu adalah suatu sikap keraguan antara adil dan menyimpang. ${ }^{32}$ Dari kata qashd pula setiap orang memperoleh pengertian negatif seperti memaksa dan cacat. Pemkanaan seperti ini pada prinsipnya ungkapan yang bersifat ambigu.

Keenam, kedilan bermakna al-Oawwam dan al-Hishsh. Kata pertama berasal dari kata qwm yang artinya tegak, lurus, dan jujur. ${ }^{33}$ Kata ini sesungguhnya ditekankan pada aspek ke-istiqamah-an dan kejujuran sesorang dalam melaksanakan aktivitas hidup baik spiritual maupun sosial. Sedangkan kedua bermakna memotong, membagi, dan jelas atau terang. Dalam arti membagikan dapat terkait dengan distribusi kekayaan yang wajib dilakukan dengan cara jelas dan terang-terangan yang menyangkut obyek yang dibagikan dan kepada subyek yang mnejadi tujuan distribusi, baik perorangan, kelompok atau kelas sosial. ${ }^{34}$

Paparan di atas menggarisbawahi tentang pentingnya menegakkan sistem keadilan dalam berbagai aspek kehidupan umat manusia, termasuk bidang ekonomi, dan upaya ini mendapatkan peneguhan secara teologis dari al-Qur'an dengan menkankan term-term positif mengenai keadilan. Term-term positif tersebut sebagaimana yang telah dijelaskan di muka semisal al- 'adl, al-qisth, al-qashdh, al-qawwam al-hishsh, al-mizan, dan al-wasath. Dengan demikian peggunaan kata keadilan dengan makna tersebut sangat relatif diklaim sebagai kebenaran tergantung situasi dan kondisi dimana ia dipraktikkan. Persoalan yang terpenting adalah penegakan keadilan dalam berbagai aktivitas mu'amalat itu adalah mutlak adanya dengan cara menjaga kemaslahatan yang lima (ushul al-khamsah) dengan tujuan memperoleh keadilan yang tertuang sebagai maqashid as-asyari'ah.

\section{Teori Keadilan dalam Hukum dan Ekonomi Syari'ah}

Keadilan sebagai persoalan yang sangat emergensi bagi kehidupan manusia setidaknya dapat dijadikan sebagai tujuan inti dalam melaksanakan kegitan-kegiatan yang bersifat sosial. Dalam bidang hukum misalnya, keadilan menjadi bagian yang tidak terpisahkan dari proses penetapan hukum oleh pihak hakim maupun ilmuan untuk

\footnotetext{
${ }^{30}$ Ibnu Manzur, et.al, hlm.353.

${ }^{31}$ Os., an-Nahl (16) ayat: 9, Qs., Ma idah (5) ayat: 66, Os., Lukman (31) ayat: 32.

${ }^{32}$ Al-Raghib al-Asfahani, Mu'jam Mufradaat..., 419.

${ }^{33}$ Os., an-Nisa' (4) ayat: 135 dan 127, Os., 'Ali 'Imran (3) ayat 18,.

${ }^{34}$ Os., Yusuf (12) ayat: 51.
} 
menyelesaikan persoalan yang sedang mereka hadapi. ${ }^{35}$ Karena dalam perspektif agama keadilan bagian penentu dari kehendak ilahi yang bersifat adil sehingga tidak heran ketika syari'at agama lazim mendefiniskan dan menentukan tujuan keadilan itu berdasarkan adil yang telah ditentukan Allah SWT.

Atas dasar inilah para pelaku keadilan (hakim) membaginya menjadi dua, yaitu: pertama, keadilan substantif yang merupakan aspek internal dari suatu hukum dan elemen-elemen keadilan yang terkandung dalam hukum adalah deklarasi tentang kebenaran dan kesalahan. ${ }^{36}$ Macam keadilan ini dideklarasikan oleh al-Ghazali, Najamuddin atTufi, Muhammad at-Thahir bin Asyur dengan konsep maslahah sebagai maqashid syari 'ahnya. ${ }^{37}$ Kedua, keadilan prosedural yang merupakan aspek eksternal dari syari'at yang dengannya keadilan substantif dapat tercapai. ${ }^{38}$ Aspek ini pada dasarnya dapat dikatakan sebagai keadilan formal yang dimanifestasikan dalam tingkatan regularitas, ketelitian, dan netral dalam aplikasi. Teori ini banyak digagas oleh kalangan Imam Syafi i dan pengikutnya. ${ }^{39}$

Dari penjelasan di atas dapat digambarakan bahwa menjaga kemaslahatan menjadi dasar pokok untuk meneggakkan keadilan dalam bidang hukum. Apalagi kalau dihubungkan dengan problema rekonstruksi dan dekonstruksi hukum maka maslahah mutlak tidak bisa diabaikan. Pembaharuan dalam istinbath hukum Islam dalam bidang akhwal al-Syakhsyiah misalnya khusus yang terkait dengan perkawinan beda keyakinan. Para tokoh pembaharu hukum Islam semisal Mahmud Syaltut menetapkan tidak boleh perkawinan terjadi antara laki-laki muslim dengan wanita kitabiyah. Karena melihat kondisi dan kenyataan bahwa saat itu, para laki-laki yang telah menikah dengan wanita kitabiyah mengikuti agama istrinya. ${ }^{40} \mathrm{Di}$ sinilah Syaltut sebetulnya menetapkan kemaslahatan terhadap pemeliharaan agama bagi kaum laki-laki yang telah memeluk agama Islam agar tetap mempertahankan agamanya.

Dalam bidang ekonomi, persoalan maslahat untuk menegakkan keadilan hukum nampak jelas dari statemen As-Syatibi yang mewajibkan setiap umat untuk memenuhi kebutuhan hidupnya. Karena satu-satunya dasar untuk menjaga maslahah dharuriyat yaitu menjaga kematian (hifzu an-nafs) itu dengan menetapkan hukum wajib bagi setiap orang

${ }^{35}$ Deni Kamaludin Yusuf, "Azas Azas Bantuan Hukum dan Peran Hakam dalam Penegakan Hukum: Studi Keritis atas Tafsir Al-Qur'an Surat AL-Nisa' Ayat 135," Syariah 17, no. Stddi Hukum Islam (2015). Volume 17, No. 13, Desember 2015.

${ }^{36}$ Al-Ghazali, al-Mustasyfa fi 'Ilm al-Ushul (Beirut: Dar al-Kutub al- 'ilmiyah, 1983). hlm. 139-140.

${ }^{37}$ Abu Ishaq al-Syatibi, al-Muwafaqat fi Ushul al-Syrai' ah (Beirut: Dar al-Fikr, n.d.). hlm. 25-37.

${ }^{38}$ Muhammad al-Thair bin 'Asyur, Maqashid As-Syari'ah al-islamiyah (Tunisia: t.t.p, 1946). hlm. 63.

${ }^{39}$ Muhammad bin Idris Al-Sayfi'i, Ar-Risalah (Kairo: Mustafa Bab al_Halabi, 1968). jilid I, hlm. 492493.

$4^{\circ}$ Abd. Salam Arief, Pembaharuan Hukum Islam Anatara Fakta dan Realita, Kajian Pemikiran Hukum Islam Syaikh Mahmud Syaltut (Yogyakarta: LESFI, 2003). hlm. 120. 
untuk memenuhi kebutuhan hidupnya seperti kebutuhan primer, skunder, dan thertier. ${ }^{41}$ Lebih jauh ia mengemukakan bahwa seluruh kegiatan ekonomi manusia baik produksi, konsumsi dan distribusi adalah sebagian kewajiban untuk memperoleh kebaikan di dunia maupun di akhirat. Dengan demikian, seluruh kegiatan perekonomian yang mengandung kebajikan untuk umat disebut dengan kebutuhan. ${ }^{42}$

Konsep penegakan keadilan lewat pemeliharaan maslahat dengan tujuan maqhasid al-syari'ah atau kepentingan umum, dapat tercermin dalam bidang perpajakan. Al-syatibi melontarkan pandangannya bahwa tujuan perpajakan yang harus dibebankan kepada rakyat adalah menjadi tanggung jawab besar dalam merealisasikan maslahah (keadilan secara umum). Oleh karena itu, ketika pihak pemerintahan mengenakan pajak-pajak baru bagi rakyatnya, maka hal ini menjadi kewajiban yang dibebankan kepada rakyat untuk diindahkan, sekalipun pajak pengeluaran tersebut belum pernah dikenal dalam sejarah ataupun masyarakat luas. ${ }^{43}$ Dalam masalah ini, menurut hemat penulis bahwa al-Syatibi mengunakan analisis kedua, yaitu dengan pemahaman 'illah, dimana beliau mewajibkan perpajakan tersebut, karena semata untuk terjaganya keadilan ekonomi secara umum bagi rakyat. Al-Syatibi dengan konsep maqashid al-syari ahnya tidak terhenti pada fokus kajian kepentingan umum, tetapi beliau menjelaskan tujuan perpajakan itu secara terinci. Dimana ia mengemukakan bahwa tujuan dibebankannya serta diwajibkannya perpajakan bagi rakyat adalah untuk menjaga keadilan sosial dan ekonomi bagi seluruh warga negaranya. ${ }^{44}$ Konsep keadilan sosio-ekonomi al-Syatibi dalam perpajakan, ${ }^{45}$ banyak diteropong lewat doktrin teologis, yaitu larangan-larangan untuk menumpukkan harta benda, kekayaan tidak boleh beredar hanya di tangan orang-orang kaya. ${ }^{46}$ Kelebihan harta yang dimiliki hamba Tuhan harus disumbangkan kepada faqir miskin, janda-janda, dan anak yatim. Karena itu, pihak yang berwajib dalam hal ini pemerintahan menurut al-Syatibi mengambil peranan penting dalam mewajibkan rakyat dalam membayar pajak untuk

${ }^{41}$ M. Fahim Khan, Shatibi's of Sari'ah and same Imflication for Consumerr Theory (New York: P36, 2006). 193.

${ }^{42}$ Adi Warman Karim (Jakarta: PT. Raja Grafindo Persada, 2004), hlm, 15.

${ }^{43}$ Musthafa Zaid, Al-Mașlaḥaḥ Fi al-Tasyrī al-Islāmi wa Najm al-Dīn al-Thūfi, (Mesir: Dār al-Fikr al'Arabi, 1964), hlm 127-132; Husain Hamid, Nazariyah al-Maslahah fi al-Figh al-Islami (Kairo: Dar an-Nahdah al-Arabiyyah, 1971), hlm, 159.

${ }^{44}$ Yusuf Musa, , al-Fiqh al-Islam (Kairo: Dar al-Kutub al-Haditsah, 1956), hlm, 123-124. Oleh Karena keadilan itu telah disinyalir dalam al-Qur'an, maka manusia sebagai makhluk Tuhan dikaruniakan akal pikiran menjadi sebuah kewajiban untuk dilaksanakan, meskipun terhadap sanak sendiri dan keluarga. Lihat Os., an-Nisa' (4) : 135. Begitu juaga Tuhan mememrintahkan untuk tidak mau dipaksa oleh orang lain untuk tidak berbuat adil, karena berbuat adil itu menjamin jalan taqwa. Lihat Os., al-Ma idah (5): 8. Di sisi yang lain keadilan adalah azaz yang kuat bagi tegakknya kehidupan masyarakat manusia, dan hukum Islam telah menjadikan keadilan sebagai ajaran moralitas yang tidak bisa dilanggar, yaitu dengan menyangkutkan perintah berbuat adil dengan berbuat ihsan.

${ }^{45}$ Asghar Ali Enginer, Islam dan Teologi Pembebasan, terj. Agung Prihantono (Yogyakarta: Pustaka Pelajar, 2003), hlm, 57-58.

${ }^{46}$ Os. An-Nahal (16) : 91, Os., al-Ma'idah (5) : 8, dan Os., at-Taubah (9) :34-35. 
mengantisipasi monopoli pemilikan harta di antara umat demi terwujudnya perinsip keadilan ekonomi dan sosial. ${ }^{47}$

Dalam ekonomi perdagangan, faktor keadilan juga menjadi salah satu penentu terjadinya aktivitas pertukaran antara satu pihak dengan pihak lain. Bahkan Ibnu Taimiyah sebagai Syaikh al-Islam tidak luput dari memperbincangkannya terutama dalam penentuan harga serta laba yang adil untuk masyarakat. Hal ini dilakukan dalam rangka menjaga kemaslahatan umum serta menghindari eksploitasi para pedagang sehingga sirkulasi perekonomian berjalan dengan normal dan dapat mensejahterakan semua pihak. la mengeksplorasi nilai keadilan itu lewat stetmennya kompensasi yang setara ('iwadh almistsl) dan harga yang setara (tsaman al-Misl). Lebih jauh Ibnu Taimiyah menyimpulkan bahwa " kompensasi yang setara akan diukur dan ditaksir oleh hal-hal yang setara, ${ }^{48}$ dan inilah esensi keadilan (nafs al-Adl)" ${ }^{49}$ Di tempat yang lain, ia membedakan antara dua jenis harga, yakni harga yang tidak adil dan dilarang serta harga yang adil dan disukai. ${ }^{50}$ Ibnu Taimiyah menganggap harga yang setara sebagai harga yang adil. Dengan demikian tidak heran ketika Ibnu Taimiyah menggunakan kedua istilah tersebut secara bergantian.

\section{Hukum Perjanjian Syari'ah: Sebuah Gambaran Umum}

Perjanjian dalam bahasa Arab dikenal dengan istilah mu'ahadah ittifa' atau akad. Akad merupakan cara yang diridhai Allah dan harus ditegakkan isinya, dan di dalam alQuran setidaknya ada dua istilah yang berkaitan dengan perjanjian yaitu kata akad (alaqadu) yang berarti perikatan atau perjanjian, dan kata 'ahd (al-ahdu) yang berarti masa, pesan, penyempurnaan dan janji atau perjanjian. ${ }^{51}$ Akad merupakan perjanjian antara kedua belah pihak yang bertujuan untuk saling mengikatkan diri tentang perbuatan yang akan dilakukan dalam suatu hal, yang diwujudkan dalam ijab (penawaran) dan qabul (penerimaan) yang menunjukkan adanya kerelaan secara timbal balik antara kedua belah pihak dan harus sesuai dengan kehendak syariat. Ini berarti hukum perjanjian Islam pada prinsipnya juga menganut asas kebebasan berkontrak yang dituangkan dalam antaradhin sebagaimana diatur dalam Qs. An-Nissa ayat 29 dan hadits Nabi Muhammad saw, yaitu suatu perikatan atau perjanjian akan sah dan mengikat para pihak apabila ada kesepakatan (antaradhin) yang terwujud dalam dua pilar yaitu ijab (penawaran) dan qabul (penerimaan). ${ }^{52}$

\footnotetext{
${ }^{47}$ Muhammad Yusuf Musa, et al, hlm. 125.

${ }^{48}$ Ibnu Taimiyah, Majmu ' Fatawa Syaikh al-Islam (Riyadh: Matabi' al-Riyadh, 1963), hlm, 521.

${ }^{49}$ Ibnu Taimiyah, et al, hlm.42.

${ }^{50}$ Ibnu Taimiyah, al-Hisab fi al-Islam (Kairo: Dar al-Sha 'b, 1976), hlm. 25.

${ }^{11}$ Ahmad Abu al-Fath, Kitab al-Mu'amalat fi asy-Syari' ah al-islamiyyah wa al-Qawanin al-Mishriyyah (Mesir: Matba'ah al-Busfir, 1913), hlm, 125-139; As-Syauqani, Fath al-Qadir (Mesir: Mustafa Bab al-Halabi,

$5^{2}$ Gemala Dewi dkk. dalam M. Tahir Azhary, Bahan Kuliah Hukum Perikatan Islam di Fakultas Hukum Universitas Indonesia tanggal 16 Februrari 1998.
} 1964), Jild II, hlm.4. 
Adanya suatu akad mengakibatkan para pihak terikat secara syariah berupa hak dan kewajiban yang harus dipenuhi oleh masing-masing pihak sesuai dengan prinsip syariah. Sahnya suatu perjanjian menurut hukum Islam ditentukan dengan terpenuhinya rukun dan syarat suatu akad. Rukun adalah unsur yang mutlak harus dipenuhi dalam suatu hal, peristiwa dan tindakan, sedangkan syarat adalah unsur yang harus ada untuk sesuatu hal, peristiwa dan tindakan tersebut. Rukun akad yang utama dan merupakan unsur penting dalam suatu akad/perjanjian adalah ijab dan qabul. ${ }^{53}$ Sementara itu, yang menjadi syarat dalam akad berkaitan dengan subyek akad dan obyek akad. Subyek akad adalah subyek hukum pada umumnya yaitu pribadi-pribadi baik manusia maupun badan hukum yang pada dirinya terdapat pembebanan kewajiban dan perolehan hak. Adapun syarat yang harus dipenuhi seseorang dalam suatu akad adalah : aqil (berakal/dewasa), tamyiz (dapat membedakan) sebagai tanda kesadaran, dan mukhtar (bebas melakukan transaksi/bebas memilih). ${ }^{54}$

Syarat-syarat yang telah disebut di atas adalah syarat sebelum terjadinya perjanjian. Sedangkan syarat yang menyebabkan perjanjian menjadi sah secara syari'ah adalah sebagai berikut: Pertama. tidak menyalahi hukum syariah yang disepakati adanya, syarat ini mengandung pengertian setiap orang pada prinsipnya bebas membuat perjanjian tetapi kebebasan itu ada batasannya yaitu tidak boleh bertentangan dengan syariah Islam baik yang terdapat dalam al-Quran maupun Hadist. Apabila syarat ini tidak terpenuhi maka akan mempunyai konsekuensi yuridis perjanjian yang dibuat batal demi hukum. Syarat sahnya perjanjian ini menurut Hukum Perdata mengenai syarat sahnya perjanjian yang diatur dalam Pasal 1320 KUHPerdata disebut dengan kausa halal. Kedua, harus sama ridha dan ada pilihan, syarat ini mengandung pengertian perjanjian harus didasari pada kesepakatan para pihak secara bebas dan sukarela, tidak boleh mengandung unsur paksaan, kekhilafan maupun penipuan. Apabila syarat ini tidak terpenuhi dan belum dilakukan tindakan pembatalan maka perjanjian yang dibuat tetap dianggap sah. Ketiga, harus jelas dan gamblang, sebuah perjanjian harus jelas apa yang menjadi obyeknya, hak dan kewajiban para pihak yang terlibat dalam perjanjian. Apabila syarat ini tidak terpenuhi maka perjanjian yang dibuat oleh para pihak batal demi hukum sebagai konsekuensi yuridisnya. Syarat sahnya perjanjian ini menurut Hukum Perdata mengenai syarat sahnya perjanjian yang diatur dalam Pasal 1320 KUHPerdata disebut dengan adanya obyek tertentu.

Apabila salah satu syarat tidak dapat terpenuhi mempunyai konsekuensi yuridis terhadap perjanjian tersebut dapat dibatalkan atau batal demi hukum, sedangkan bagi perjanjian yang sah akan mengikat bagi para pihak sebagai undang-undang dan para pihak

53 Syamsul Anwar, Hukum Perjanjian Syari'ah, Studi tentang Teori Akad dalam Fikih Muamalah (Jakarta: PT. Raja Grafindo Persada, 2007), hlm., 98.

${ }^{54}$ Mustafa Az-Zarqa, al-Figh al-Islam fi Tsaubihi al-Jadid (Damaskus: Matabi' Alifba' al-Adib, n.d.), jilid, I, hlm, 312; Wahbah az-Zuhaili, Figh Islam wa Adilatuhu, para. Objek kajian ini telah wujud jelas dan dapat diserahkan pada saat terjadinya akad. 
wajib melaksanakan perjanjian secara sukarela dengan itikad baik serta tidak bisa memutuskan perjanjian tersebut secara sepihak. Apabila salah satu pihak mengabaikan perjanjian maka akan mendapat sanksi dari Allah di akhirat nanti.

Suatu perjanjian dapat dikatakan sah jika telah terpenuhi syarat serta unsur-unsur pokok yang terkandung dalam hukum perjanjian tersebut. Meskipun demikian perjanjian tersebut tidak menjadi sempurna jika tidak didasari dengan azas-azas yang terang di dalamnya. Adapun asas-asas hukum perjanjian yang dimaksud dalam konteks hukum Islam, yaitu azas ilahiyah, ${ }^{55}$ yang memberikan spirit bahwa segala bentuk transaksi harus ada interpensi ketuhanan. Dengan kata lain bahwa setiap orang jika mengerjakan segala sesuatu harus berada atas segala keridhaannya sehingga keberkahan, kemanfaatan, kesejahteraan dunia dan akhirat terjamin. Kedua, al-hurriyah ${ }^{56}$ (kebebasan), asas ini mengandung pengertian para pihak bebas membuat suatu perjanjian atau akad (freedom of making contract). Asas al-hurriyah ini dikenal sebagai asas kebebasan berkontrak. Ketiga, al-musawah ${ }^{57}$ (persamaan atau kesetaraan. asas ini mengandung pengertian bahwa para pihak dalam perjanjian mempunyai kedudukan yang sama yaitu mempunyai kesetaraan atau kedudukan yang seimbang dalam menentukan term of condition dari suatu akad. Asas ini menunjukkan bahwa semua orang mempunyai kedudukan yang sama di depan hukum (equality before the law) dan yang membdakan kedudukan seseorang di sisi Allah adalah derajat ketakwaannya. Kempat, al-Adalah (keadilan), perjanjian yang dibuat senantiasa mendatangkan keuntungan yang adil dan berimbang dan tidak boleh mendatangkan kerugian bagi salah satu pihak. Kelima, al-ridha (kerelaan)..$^{58}$ segala transaksi yang dilakukan atas dasar kerelaan antara masing-masing pihak dan didasarkan pada kesepakatan bebas dari para pihak dan tidak boleh mengandung unsur paksaan, tekanan, dan penipuan. Asas ini dikenal dengan asas konsensualisme dalam hukum Perdata. Keenam, ash-shidq/al-amanh (kebenaran dan kejujuran) ${ }^{59}$, setiap muslim wajib untuk berkata benar dan jujur terutama dalam hal melakukan perjanjian dengan pihak lain, sehingga kepercayaan menjadi sesuatu yang esensial demi terlaksananya suatu perjanjian atau akad. Ketujuh, al-kitabah (terulis, ${ }^{60}$ setiap perjanjian hendaknya dibuat secara tertulis untuk kepentingan pembuktian jika di kemudian hari terjadi sengketa dan dalam pembuatan perjanjian tersebut hendaknya disertai dengan adanya saksi-saksi serta prinsip tanggung jawab individu. Bentuk tertulis ini dimaksudkan apabila terjadi sengketa di kemudian hari terdapat alat bukti tertulis mengenai sengketa yang terjadi.

\footnotetext{
${ }^{55}$ Fahurrahman Djamil, Hukum Perjanjian Syari 'ah", dalam Kompelasi Hukum Perikatan oleh Mariam Daruz Badzrulzaman (Bandung: Citra Aditya Bakti, 2001), hlm, 249-251. Lihat al-Qur'an Os, al-An'am (6), hlm.162.

${ }^{56}$ WJS Poerwadarminta, Kamus Umum Bahasa Indonesia (Jakarta: Balai Pustaka, 1986), hlm, 103. Lihat QS., al-Baqarah (2) ayat: 156.

${ }^{57}$ Qs., Al-Hujurat ayat 13.

${ }^{58}$ Os., An-Nissa (4) ayat: 29

${ }^{59}$ Os., Al-Ahzab ayat 70

${ }^{60}$ Os., al-Baqarah (2) ayat 282-283.
} 


\section{Teori Keadilan dalam Perjanjian Syari ah}

Menurut historisnya bahwa aktivitas perjanjian telah dilakukan semenjak manusia berada dalam alam arwah. Perjanjian yang dimaksud adalah sangat bersifat absolute teologis. Dimana setiap manusia yang akan lahir ke dunia di perintah oleh Tuhan sendiri untuk diakui sebagai Tuhannya dan tidak boleh melanggar perintahnya di dunia. ${ }^{61}$ Perjanjian yang dilakukan manusia di dunia merupakan implementasi dari perjanjian yang telah dilakukan secara pasti bersama Tuhannya. Itulah sebabnya perjanjian di dunia tidak boleh keluar dari norma atau aturan-aturan yang telah ditentukan oleh Tuhan baik dalam al-Qur'an maupun sunnah Rasulullah SAW. Adanya syarat dan rukun yang harus diikuti merupakan impelementasi dari kehendak manusia untuk menjaga kemungkinankemungkinan yang akan terjadi di kemudian hari setelah melakukan perjanjian. ${ }^{62}$ Karena itu tugas manusialah yang berusaha untuk meminimalisir akibat buruk dari perjanjian yang hendak dilakukannya. Persyaratan sebelum terjadinya sangat menentukan baik dan buruk keberlangsungannya. Karena itu, menegakkan keadilan sebelum perjanjian dilangsungan dalam transaksi mu'amalat menjadi kewajiban yang tidak boleh ditinggalkan dalam rangka keselamatan maupun perdamaian. Misalanya, implementasi nilai keadilan dalam praperjanjian, proses perjanjian, dan pascaproses perjanjian.

Ketetapan ulama mengenai subyek perjanjian yang harus tamyiz merupakan implementasi dari penegakaan keadilan secara prosedural. Karena tamyiz merupakan peralihan dari batas tertinggi dari kekanak-kanakan seseorang dan secara mental emosional mereka mampu membedakan perkataan maupun perbuatan bermanfaat yang dapat mendatangkan kemaslahatan baik untuk dirinya maupun orang lain. ${ }^{63}$ Lebih adil lagi ketika penentuan batas umur maksimal anak untuk menginjak tamyiz itu dalam perjanjian syari'ah tidak ada sehingga dapat mendorong terjadinya semangat pakar hukum Islam untuk menetapkan tamyiz itu menurut pendapat serta pengalaman masing-masing sesuai situasi dan kondisi di mana saja mereka tinggal. ${ }^{64}$ Keadilan dalam hal ini pada prinispnya bermakna adil secara proporsional, ${ }^{65}$ yaitu pemberian kesempatan kepada anak yang sudah tamyiz untuk menanggung beban dan kewajiban masing-masing sesuai dengan kemampuannya. ${ }^{66}$ Selain memberikan kesempatan untuk mengambil bagian dalam

${ }^{61}$ Abudin Nata, Metodologi Studi Islam (Jakarta: Rajawali Press, 2002), hlm. 16.

${ }^{62}$ Kartini Muljadi, Perikatan Pada Umumnya (Jakarta: PT. Raja Grafindo Persada, 2004), hlm, 16-17.

${ }_{3}^{6}$ Muhammad Kholid, "Prinsip Prinsip Hukum Ekonomi Syariah dalam Undang Undang tentang Perbankan Syariah," Asyari'ah 20, no. Perbankan Syariah (2018): Volume 20., No. 2, Desember 2018, https://doi.org/https://doi.org/10.15575/as.v2oi2.3448.

${ }^{64}$ Imam Ahmad bin Hanbal, al-Musnad, Juz. II. Tahqiq, Abd al-'Allah Muhammad al-Darwish, juz II (Bairut: Dar al-Fikr, n.d.), 599.

${ }_{5}^{6}$ al-Imam Abu Hamid al-Ghazali, al-Mustashfa fi 'Ilm al-Ushul (t.t.p: Dar al-Kutub al-'Ilmiyah, n.d.), hlm, 35 .

${ }^{66}$ Mahir Amin, "Konsep Keadilan dalam Filsafat Hukum Islam," Ad-Daulah: Jurnal Hukum dan Perundangan Islam 4, no. Hukum Islam dan Perundang Undangan (2014): Volume 4, No., 2, Oktober 2014, https://doi.org/https://doi.org/10.15642/ad.2014.4.02.322-343. 
mempertanggungjawabakan beban hukum juga sebagi edukasi mandiri sehingga dapat mempercepat kematangan anak tersebut dalam menanggung beban hukum dalam segala aspek kehidupannya. ${ }^{67}$

Implementasi keadilan juga tercermin dari penentuan jumlah pelaku perjanjian meskipun dalam syaratnya itu nampak harus ta'addud (berbilang). ${ }^{68}$ Karena dalam bayangannya bahwa pelaku janji tersebut harus dilakukan oleh orang yang jumlahnya lebih dari tiga orang. Tetapi yang dimaksud di sini adalah ada pasangan meskipun hanya jumlahnya dua orang. Jika para pihak akan melakukan perjanjian setidaknya ia dapat menjunjung nilai keadilan apakah berbentuk keadilan sosial, keadilan ekonomi, hukum, dan lainya sangat tergantung dari bentuk dan jenis perjanjian yang dilakukannya. ${ }^{69} \mathrm{Kalau}$ perjanjiannya itu terkait dengan bakti sosial maka perjanjian tersebut dapat mengimplementasikan nilai keadilan sosial. Begitu juga dengan keadilan ekonomi jika para pihak tersebut sama-sama terlibat dalam perjanjian syirkah (kerjasama) dalam bidang produksi, konsumsi, dan distribusi maka secara otomatis telah mengimplementasikan keadilan ekonomi. ${ }^{70}$ Sebagai antitesinya bahwa seseorang yang akan melakukan perjanjian tanpa ada kawannya tentu tidak bisa melaksanakan suatu perjanjian dan pada ujungnya tidak dapat mengimplementasikan keadilan seperti para pihak yang melakukan perjanjian. Pada intinya perjanjian tidak bisa dilakukan oleh satu orang tanpa ada orang lain sebagai mitra yang terlibat di dalamnya.

Mengimplementaiksan nilai keadilan tidak habis-habisnya dalam perjanjian. Paling tidak dalam tulisan ini hanya memformulaiskan hal-hal yang pokok saja. Taruh misalnya penetapan nilai keadilan dalam prasyarat perjanjian yang disebut sebagai iradah almunfaridah. Syarat ini pada dasarnya memberikan kebebasan dengan sebebas-bebasnya kepada para pihak untuk menentukan siapa mitra, dimana dilaksanakan, dan obyek yang akan diperjanjikan. ${ }^{71}$ Artinya pemilihan tiga aspek di atas tidak bisa diinterpensi oleh orang lain meskipun dalam bentuk motivasi, saran, profokasi dan lain sebagainya. Dalam tradisi figh kebebasan tersebut adalah khiyar..$^{72} \mathrm{Hal}$ ini sangat bersifat emergensi karena tujuan dari pelaksanaan perjanjian itu adalah terjalinnya sikap ukhuwah bagi masing-masing pihak. Dimana para pihak dapat mengimplementasikan keadilan dengan semangat

\footnotetext{
${ }^{67}$ Zaenudin Mansyur, "Relevansi Teori Maslahah Najamuddin At-Thufi dalam Istinbath Hukum Anak Sebagai Mahkum Alaih," Istinbath 27, no. Hukum Islam (2018): 379, https://doi.org/https://doi.org/10.20414/ijhi.v17i2.99.

${ }_{68}$ As-Sanhuru, Mashadir al-Haqq fi al-Fiqh al-Islami (Kairo: Ma'had ad-Dirasat al-'Arabiyyah al'Aliyah, 1956), jilid IV, hlm, 134. hlm. 176.

${ }_{69}$ A. Ridwan Halim, Pengantar Ilmu Hukum dalam Tanya Jawab (Jakarta: Ghalia Indonesia, 2005),

${ }^{70}$ Jurgen Habermas, Moral Consoiouness and Communicative Action (Cambidg: MIT Press, 1990), hlm, 200.

${ }^{71}$ Mustafa Az-Zarqa, al-Fiqh al-Islam fi Tsaubihi al-Jadid, hlm, 312.

${ }^{72}$ Ala 'uddin al-Kasani, Badai' Ash-Shanai' fi Tartib Syara' (Mesir: Syirkah al-Maktubah, n.d.), hlm, 174; Ya'cub, Kode Etik Dagang Menurut Islam Pola Pembinaan Hidup dalam Berekonomi (Bandung: CV. Diponegoro, 1984), hlm, 79.
} 
menjaga salah satu kemaslahatan yang lima tergantung bentuk aktivitas janji yang dilakukannya. ${ }^{73}$ Misalnya menjaga harta dari kebangkrutan dapat ditunjukkan dengan cara menjaga kejujuran di antara kedua belah pihak dalam melakukan transaksi perjanjian. Menunjukkan sikap ridha antara kedua belah pihak sehingga dapat menghindari komplik internal yang berujung pada terancamnya nyawa masing-masing. ${ }^{74}$

Dalam proses perjanjian, nilai keadilan juga dapat diimplementasikan dari aktivitas ijab qabul yang dilakukan oleh para pihak pelaku perjanjian. Karena maksud ditetapkannya adalah untuk mengetahui sejauhmana kesiapan serta kerelaan masing-masing pihak dalam perjanjian. ${ }^{75}$ Eksistensi ijab merupakan sikap rela atau sepakat yang harus ditunjukkan oleh pihak yang menawarkan janji. Sedangkan qabul merupakan perwujudan dari kebebasan serta keikhlasan kehendak pihak penerima janji. Ketika kedua belah pihak telah menunjukkan satu kata, yaitu kata sepakat maka perjanjian yang dilakukan setidaknya dapat memunculkan nilai keadilan tergantung bentuk janji yang dilakukan. Jika perjanjian tersebut erat kaitannya dengan aktivitas hibah, shadaqah, hadiyah wasyiat, waris maka perjanjian tersbut dapat memasuki ranah impelemntasi nilai keadilan ekonomi, dan sosial. Jika berkaitan dengan perjanjian shuluh maka stidaknya dapat mewujudkan nilai keadilan hukum agar para pihak terjamin keamanan jiwa fisiknya dari ancaman kematian. ${ }^{76}$ Misalnya pembagian warisan yang semestinya harus dilakukan dengan dua banding satu (2:1) tetapi keinginan ahli waris harus satu banding satu (1:1). Karena kalau tidak dilakukan pembagian dengan 1:1 maka akan terjadi pertumpahan darah antara kedua belah pihak. Disinilah nilai keadilan harus ditegakkan dengan mempertimbangan kemaslahatan yang ada agar tercapai maqashid syari'ahnya, yaitu terjagannya kedua belah pihak tadi ancaman kematian.

Pernyataan kehendak lewat tradisi ijab dan qabul dengan teknis yang bervariasi semisal boleh dengan ucapan, utusan, tulisan, isyarat, diam-diam, dan diam semata itu menandakan adanya implemntasi keadilan. Karena situasi dan kondisi dimana perjanjian dilakukan sangat menentukan para pihak untuk memilih teknis tersebut. Artinya perjanjian yang dilakuakan oleh pihak yang normal secara fisik tidak bisa dipaksakan untuk dipraktikan oleh para pihak yang cacat fisik..$^{77}$ Begitu juga perjanjian tersebut yang erat kaitannya dengan jarak tinggal para pihak berbeda, sementara alat komunikasi tidak memungkinkan untuk diterapkan, maka dalam kondisi ini harus dilakukan dengan cara tulisan maupun utusan. Begitulah seterusnya, dimana wujud kebebasan dalam memilih teknis perjanjian

\footnotetext{
${ }^{73}$ Jusmaliani, Bisnis Berbasis Syariah (Jakarta: Bumi Aksara, 2008), hlm, 45-56.

${ }^{74}$ Muhammad Dja'far, Etika Bisnis Islam Tataran Teoritis dan Praktis (Malang: UIN Malang Press, 2008), hlm., 108.

${ }^{75}$ Syamsul Anwar, et al, hlm. 143 .

${ }^{76}$ Abu Ishaq As-Syatibhi, al-Muwafaqat fi Ushuli as-Syari' ah (Beirut: Dar al-Fikr, n.d.), hlm, 13.

${ }_{77}$ Muhamad Syukri Albani Nasution, , Filsafat Hukum Islam (Jakarta: PT. Raja Grafindo Persada, 2013), hlm, 73.
} 
itu harus dilaksanakan agar kebutuhan masing-masing pihak dapat terlaksana sesuai dengan harapan. ${ }^{78}$

Penetapan nilai keadilan dalam perjanjian syari'ah juga tercermin dalam proses realisasi hak dan kewajiban setelah akad perjanjian berlangsung. Dimana pihak yang menawarkan, berhak memperoleh bayaran yang seimbang dari kualitas dan kuantitas barang yang ditawarkannya. Sedangkan pihak peminta berhak juga untuk memperoleh barang yang sesuai dengan permintaanya. Begitu juga dengan realisasi kewajiban para pihak harus bertanggung jawab atas apa yang menjadi kewajiban masing-masing. ${ }^{79}$ Pihak yang menawarkan perjanjian juga wajib menyerahkan serta melepas obyek yang diperjanjiakannya secara rela dan ikhlas. Sedangkan peminta juga harus rela menyerahkan sejumlah harga kepada penawar sebagaimana yang telah ditentukan dalam perjanjian seperti harga pokok, dan laba. Keadilan yang dimaksud dalam hak dan kewajiban ini dapat dikatagorikan keadilan bermakna al-mizan ${ }^{80}$ yaitu suatu persoalan dapat diukur keadilannya dengan sejauh kedua belah pihak yang melakukan perjanjian itu dapat menyeimbangkan obyek perjanjian secara kualitas dan kuantitas.

\section{Simpulan}

Implementasi keadilan dalam pra proses dapat dipraktetkkan lewat penetapan para pihak yang harus disyaratkan tamyiz. Hal ini menjadi penting mengingat bahwa resiko dari sebuah perjanjian hanya berlaku paten pada pelakunya bukan untuk orang lain meskipun orang tuanya sendiri. Selain tamyiz terdapat juga keadilan dalam penentuan jumlah pihak yang melaksanakan perjanjian. Karena setiap perjanjian yang dilakukan oleh satu orang maka perjanjian tidak bisa dilangsungkan. Di sinilah keadilan dalam menanggung risiko dari setiap perjanjian harus ditanggung bersama. Begitu juga dalam pra proses ini penerapan keadilan juga termanipestasi pada pembebasan bagi setiap pihak yang melakukan perjanjian, tanpa ada intervensi orang lain sekalipun dalam bentuk motivasi. Dalam proses pelaksnaan penetapan keadilan juga terdapat pada aktivitas ijab qabul para pihak pelaku perjanjian. Karena maksud ditetapkannya adalah untuk mengetahui sejauhmana kesiapan serta kerelaan masing-masing pihak dalam perjanjian. Pernyataan kehendak lewat tradisi ijab dan qabul dengan teknis yang bervariasi semisal boleh dengan ucapan, utusan dan tulisan, isyarat, diam-diam, dan diam semata adalah menandakan adanya implementasi nilai keadilan. Karena situasi dan kondisi dimana perjanjian dilakukan sangat menentukan para pihak untuk memilih teknis tersebut. Keadilan dalam

${ }^{78}$ Khoiruddin Nasution, "Pencatatan sebagai Syarat atau Rukun Perkawinan: Kajian Perpaduan Tematik dan Holistik," Musawa 12, no. Hukum Isalam dan Gender (2013): Vol. 12. No 2 Juli 2013, hlm. $166 .$, https://doi.org/https://doi.org/10.14421/musawa.2013.122.165-185.

${ }^{79}$ As-Sanhuru, Nazariyyah al- 'Aqd (Beirut: Dar al-Fikr, n.d.), hlm, 182.

${ }^{80}$ Kata al-mizan yang berate persamaan timbangan dapat dilihat dalam Ibnu Manzu, Lisan...., 446448. Begitu juga dalam Mustafa al-maraghi, tafsir...., 29-31. Dalam al-Qur'an juga dijelaslan pada Qs., alIsra' (17) ayat: 35., Qs., al-A'raf (7) ayat: 85., Qs., Hud (11) ayat: 84-85. 
perjanjian seperti ini dapat dikatagorikan sebagai keadilan proporsional. Dalam pasca proses perjanjian, bahwa nilai keadilan juga dapat dimplementasikan dalam bentuk penyerahan atau pelaksanaan hak dan kewajiban bagi masing-masing pihak. Dimana nilai keadilan dalam kondisi ini adalah al-mizan kesamaan timbangan dari segi kualitas maupun kuantitas. Artinya pihak yang melaksanakan hak dan kewajiban itu harus seimbang dan tidak boleh ada semacam pengurangan. Jual beli misalnya, bahwa pihak penjual wajib menyerahkan obyek perjanjian sesuai dengan harga yang telah ditentukan bersama. Sementara pembeli harus menyerahkan sejumlah uang sesuai dengan kuantias dan kualitasnya.

\section{Daftar Pustaka}

A. Ridwan Halim. Pengantar Ilmu Hukum dalam Tanya Jawab. Jakarta: Ghalia Indonesia, 2005 .

Abd. Salam Arief. Pembaharuan Hukum Islam Anatara Fakta dan Realita, Kajian Pemikiran Hukum Islam Syaikh Mahmud Syaltut. Yogyakarta: LESFI, 2003.

Abu Ishaq al-Syatibi. al-Muwafaqat fi Ushul al-Syrai 'ah. Beirut: Dar al-Fikr, n.d.

Adi Warman Karim. Jakarta: PT. Raja Grafindo Persada, 2004.

Ahmad Abu al-Fath. Kitab al-Mu'amalat fi asy-Syari'ah al-islamiyyah wa al-Qawanin alMishriyyah. Mesir: Matba'ah al-Busfir, 1913.

Al-Ghazali. al-Mustasyfa fi 'Ilm al-Ushul. Beirut: Dar al-Kutub al-'ilmiyah, 1983.

al-Imam Abu Hamid al-Ghazali. al-Mustashfa fi 'Ilm al-Ushul. t.t.p: Dar al-Kutub al'Ilmiyah, n.d.

Al-Isfahani, Al-Raghib. Mu 'jam Mufradat al-Fazh al-Qur'an. Beirut: Dar al-Fikr, n.d.

Al-Maraghi, Mustafa. Tafsir al-Maraghi. Beirut: Dar al-Fikr, 1944.

Al-Sayfi i, Muhammad bin Idris. Ar-Risalah. Kairo: Mustafa Bab al_Halabi, 1968.

Ala 'uddin al-Kasani. Badai' Ash-Shanai' fi Tartib Syara'. Mesir: Syirkah al-Maktubah, n.d. As-Sanhuru. Mashadir al-Haqq fi al-Fiqh al-Islami. Kairo: Ma 'had ad-Dirasat al- 'Arabiyyah al-'Aliyah, 1956.

—. Nazariyyah al-'Aqd. Beirut: Dar al-Fikr, n.d.

As-Syatibhi, Abu Ishaq. al-Muwafaqat fi Ushuli as-Syari 'ah. Beirut: Dar al-Fikr, n.d.

As-Syauqani. Fath al-Qadir. Mesir: Mustafa Bab al-Halabi, 1964.

Asghar Ali Enginer. Islam dan Teologi Pembebasan, terj. Agung Prihantono. Yogyakarta: Pustaka Pelajar, 2003. 
Burhan Ahshafa. Metodologi Penelitian Hukum. Jakarta: Reneka Cipta, 1998.

Deni Kamaludin Yusuf. "Azas Azas Bantuan Hukum dan Peran Hakam dalam Penegakan Hukum: Studi Keritis atas Tafsir Al-Qur'an Surat AL-Nisa' Ayat 135." Syariah 17, no. Stddi Hukum Islam (2015).

Fahurrahman Djamil. Hukum Perjanjian Syari 'ah", dalam Kompelasi Hukum Perikatan oleh Mariam Daruz Badzrulzaman. Bandung: Citra Aditya Bakti, 2001.

Fyzee., A.A.A. Law in the Middle East. Wasington: D.C, 1955.

Hans Wer. A Dictionary of Modern Written Arabic, Arabic-English. Beirut: Librairie du Liban, 1980.

Husain Hamid. Nazariyah al-Maslahah fi al-Figh al-Islami. Kairo: Dar an-Nahdah alArabiyyah, 1971.

Ibnu Katsir. Tafsir al- 'Azhim. Beirut: Dar al-Fikr, 1982.

Ibnu Manzur. Lisan al-Arab. Beirut: Dar al-Shadr, 1990.

Ibnu Taimiyah. Majmu ' Fatawa Syaikh al-Islam. Riyadh: Matabi' al-Riyadh, 1963.

Imam Ahmad bin Hanbal. al-Musnad, Juz. II. Tahqiq, Abd al-'Allah Muhammad al-Darwish, juz II. Bairut: Dar al-Fikr, n.d.

Imam Syafi' i. al-Risalah. Kairo: Mustafa Bab al-Halabi, 1969.

J. Million Cowan. A Dictionary of Modern Written Arabic. New York: t.t.p, 1976.

Jurgen Habermas. Moral Consoiouness and Communicative Action. Cambidg: MIT Press, 1990.

Jusmaliani. Bisnis Berbasis Syariah. Jakarta: Bumi Aksara, 2008.

Khoiruddin Nasution. "Pencatatan sebagai Syarat atau Rukun Perkawinan: Kajian Perpaduan Tematik dan Holistik." Musawa 12, no. Hukum Isalam dan Gender (2013): 166. https://doi.org/https://doi.org/10.14421/musawa.2013.122.165-185.

Lawis Ma'aluf. Kamus al-Munjid. Beirut: t.t.p, 1997.

Lexy J. Moleong. Metodologi Penelitian Kualitatif. Bandung: Remaja Rosda Karya, 1989.

M. Fahim Khan. Shatibi's of Sari'ah and same Imflication for Consumerr Theory. New York: P36, 2006.

M. Umer Chapra. Islam an The Ekonomic Challenge. Herndon: IIIT, 1992.

Mahir Amin. "Konsep Keadilan dalam Filsafat Hukum Islam." Ad-Daulah: Jurnal Hukum dan Perundangan Islam 4, no. Hukum Islam dan Perundang Undangan (2014). https://doi.org/https://doi.org/10.15642/ad.2014.4.02.322-343. 
Majma' al-Lughah al-Arabiyah. Mu'jam Alfazh al-Qur'an al-Karim. Kairo: Al-Idarah al'Ammah li al-Mu 'jamat wa Ihya' al-Turats al-Arabi, 1989.

Muhamad Syukri Albani Nasution., Filsafat Hukum Islam. Jakarta: PT. Raja Grafindo Persada, 2013.

Muhammad al-Thair bin 'Asyur. Maqashid As-Syari'ah al-islamiyah. Tunisia: t.t.p, 1946.

Muhammad Dja'far. Etika Bisnis Islam Tataran Teoritis dan Praktis. Malang: UIN Malang Press, 2008.

Muhammad Fu'ad Abdul Baqi. al-Mu 'jam alMufahras li al-faz al-Qur'an al-Karim. Jakarta: Maktab Dahlan, n.d.

Muhammad Kholid. "Prinsip Prinsip Hukum Ekonomi Syariah dalam Undang Undang tentang Perbankan Syariah." Asyari'ah 20, no. Perbankan Syariah (2018): 60-70. https://doi.org/https://doi.org/10.15575/as.v2oi2.3448.

Muljadi, Kartini. Perikatan Pada Umumnya. Jakarta: PT. Raja Grafindo Persada, 2004.

Mustafa Az-Zarqa. al-Fiqh al-Islam fi Tsaubihi al-Jadid. Damaskus: Matabi' Alifba' alAdib, n.d.

Rasyid, Rosihan A. Penyelarasan Diberlakukannya Hukum Acara Perdata Peradilan Umum Sebagai Hukum Acara Peradilan Agama Khusus dari Segi Pembuktian Zina dalam Mimbar Hukum Aktualisasi Hukum Islam. Jakarta: Direktorat Pembinaan Badan Peradilan Agama Islam, 1992.

Soekanto, Soerjono. Pengantar Penelitian Hukum. Jakarta: Universitas Indonesia Press, 1986.

Syamsul Anwar. Hukum Perjanjian Syari'ah, Studi tentang Teori Akad dalam Fikih Muamalah. Jakarta: PT. Raja Grafindo Persada, 2007.

Wahbah az-Zuhaili. Fiqh Islam wa Adilatuhu. Damaskus: Dar al-Fikr, 1989.

—. Tafsir al-Munir al- 'Aqidah wa al-Syari' ah wa al-Manhaj. Beirut: Dar al-Fikr, 1991.

WJS Poerwadarminta. Kamus Umum Bahasa Indonesia. Jakarta: Balai Pustaka, 1986.

Ya'cub. Kode Etik Dagang Menurut Islam Pola Pembinaan Hidup dalam Berekonomi. Bandung: CV. Diponegoro, 1984.

Yusuf Musa., al-Fiqh al-Islam. Kairo: Dar al-Kutub al-Haditsah, 1956.

Zaenudin Mansyur. "Relevansi Teori Maslahah Najamuddin At-Thufi dalam Istinbath Hukum Anak Sebagai Mahkum Alaih." Istinbath 27, no. Hukum Islam (2018): 379. https://doi.org/https://doi.org/10.20414/ijhi.v17i2.99.

Zaid, Musthafa. Al-Mașlaḥaḥ Fı al-Tasyrī al-Islāmi wa Najm al-Dīn al-Thūfi,. Mesir: Dār al- 
178 | Asy-Syari'ah Vol. 22 No.2, Desember 2020

Fikr al-'Arabi, 1964 .

Zakiyuddin Baidhawy. Rekonstruksi Keadilan, Etika Sosial Ekonomi Islam untuk Kesejahteraan Umum. Surabaya: Jb. Books, 2007. 
Asy-Syari'ah (P-ISSN: 2086-9029 E-ISSN: 2654-5675) is a periodical scientific journal that publishes various results of studies and research, literature review, and other scientific works whose scope covers the field of Islamic law/sharia, law and society in monodisciplinary, interdisciplinary, and multidisciplinary manners. The journal aims to expand and create innovative concepts, theories, paradigms, perspectives and methodologies in the above said scope. The Journal is published twice a year (june and december) by Faculty of Shariah and Law, Sunan Gunung Djati State Islamic University Bandung in collaboration with Asosiasi Sarjana Syariah Indonesia (ASSYI).

\section{EDITORIAL OFFICE:}

Fakultas Syariah dan Hukum UIN Sunan Gunung Djati Bandung J1. Raya A.H. Nasution No. 105 Cibiru Kota Bandung, 40614

Tlp/Fax: +022-7802278 Faks. 022-7802278

Website http://journal.uinsgd.ac.id/index.php/asy-syariah/index

E-mail: Jurnalasy-syariah@uinsgd.ac.id 